\title{
Host determinants for the development of allergy in apprentices exposed to laboratory animals
}

\author{
D. Gautrin*,\#, H. Ghezzo*, C. Infante-Rivard" ${ }^{\#}$ J-L. Malo*
}

Host determinants for the development of allergy in apprentices exposed to laboratory animals. D. Gautrin, H. Ghezzo, C. Infante-Rivard, J-L. Malo. (C)ERS Journals Ltd 2002.

ABSTRACT: The aim of this study was to evaluate whether determinants of workrelated symptoms, skin sensitization and diseases differ between atopic and nonatopic subjects starting a career with exposure to laboratory animals (LA).

A cohort of 417 apprentices in animal-health technology was prospectively followed during 32 or 44 months. The effect on the study outcomes of variables derived from questionnaire, skin reactivity, and lung function assessments at baseline were compared in atopic $(\mathrm{n}=\mathbf{2 1 2})$ and nonatopic $(\mathrm{n}=\mathbf{1 8 3})$ subjects.

Eighty-five incident cases of sensitization to a LA-derived allergen were identified, 67 among atopic and 18 among nonatopic subjects. Baseline rhinitis symptoms in contact with pets and skin sensitization to pets were associated with the development of workrelated rhinoconjunctivitis (RC) symptoms in atopic subjects, whereas perannual rhinitis symptoms and having a PC20 (provocative concentration causing a $20 \%$ fall in forced expiratory volume in one second) $\leqslant 32 \mathrm{mg} \cdot \mathrm{mL}^{-1}$ were associated in nonatopic subjects. Baseline rhinitis symptoms on contact with pets and a $P C 20$ value $\leqslant 32 \mathrm{mg} \cdot \mathrm{mL}^{-1}$ were significant determinants for developing sensitization to a specific allergen in atopic subjects only. Finally, baseline rhinitis symptoms in contact with pets and perannual rhinitis symptoms were associated with the development of occupational $\mathrm{RC}$ in atopic subjects, whereas in nonatopic subjects this was associated with having a PC20 value $\leqslant 32 \mathbf{m g} \cdot \mathbf{m L}^{-1}$

In conclusion, the determinants for the development of specific skin sensitization, symptoms and disease are different between atopic and nonatopic apprentices starting occupational exposure to laboratory-animal-derived allergens. Eur Respir J 2002; 19: 96-103.
*Dept of Chest Medicine, Hôpital du Sacré-Coeur, Montreal and "\#oint Depts of Epidemiology and Biostatistics and Occupational Health, McGill University, Montreal, Canada.
Correspondence: D. Gautrin Dept of Chest Medicine Sacré-Coeur Hospital
5400 Gouin Blvd West
Montreal
Canada H4J 1C5
Fax: 15143383123

Keywords: Bronchial responsiveness immunological sensitization occupational asthma

Received: March 262001 Accepted after revision September 5 2001

This study was supported by the Medical Research Council of Canada (grant no MT-12256). D. Gautrin is a research scholar with the Fonds de la Recherche en Santé du Québec (FRSQ).
Exposure to laboratory animal-derived allergens carries a significant risk for immunoglobulin (Ig)-Emediated sensitization and development of oculonasal and respiratory symptoms as well as occupational rhinoconjunctivitis (RC) and asthma (OA) [1]. In a prospective assessment of 342 laboratory-animal workers, Cullinan et al. [2] found that 46 (13\%) developed skin reactivity to rat urine over a 3.5-yr period. In a prospective study of 417 apprentices starting exposure to laboratory animals and seen for a 32 - to 44 -month period, $85(20 \%)$ incident cases of sensitization to at least one laboratory-animal-derived allergen were identified [3]. Interestingly, one third of these cases had probable OA as they also developed significant changes in bronchial hyperresponsiveness [4].

As for most high molecular weight occupational allergens, almost all cross-sectional studies on animal workers to date [1] have shown atopy to be a risk factor for sensitization to animal-derived allergens. In a prospective assessment, the present authors found that atopy was a risk factor for skin sensitization although the relative risk (RR) was relatively low $(\mathrm{R} R=2.2,95 \%$ confidence interval $(\mathrm{CI})=1.2-3.9)$. The only other factor associated with the development of skin sensitization to animal-derived allergens was the presence of respiratory symptoms in the pollen season ( $\mathrm{RR}=5.2$, 95\% CI=1.7-16.1) [3]. Although atopic subjects are at greater risk for sensitization, it is known that only one third of subjects will progress to symptomatic state, at least in the first 5 yrs of followup after sensitization [5]. The positive predictive value of atopy is therefore relatively low and considering that $\sim 50 \%$ of young adults are currently atopic subjects [6], therefore excluding them from entering a career in which they will be exposed to laboratory animals cannot be recommended. A non-negligible proportion of nonatopic subjects exposed to laboratory animals might also develop skin sensitization. In a pooled survey of 649 workers from four countries who were exposed to laboratory animals, $18 / 401(4.5 \%)$ nonatopic subjects had skin reactivity to rat urine [7]. Among the 85 incident cases of sensitization to a laboratory-animal-derived allergen identified in the present authors' previous study, 18 $(21 \%)$ had entirely negative skin tests to common allergens [3].

Risk factors for outcomes of allergy might well 
differ according to atopic status. The present study, therefore, aimed to examine the determinants for the development of skin sensitization to a common allergen (mites) and laboratory animal-derived allergens, as well as the development of work-related oculonasal and respiratory symptoms, occupational $\mathrm{RC}$ and probable OA, by examining atopic and nonatopic subjects separately.

\section{Material and methods}

\section{Study subjects}

Baseline characteristics of the 417 apprentices in animal-health technology recruited in five different specialized schools between 1993-1995 have been reported previously [6]. Subjects in these schools were eligible to participate in a prospective study for the duration of their vocational programme provided that they had not been exposed to the aeroallergens relevant to this study in the course of an apprenticeship or job for a total of $\geqslant 3$ months before entering the program, as assessed in a preliminary visit. Among the 417 subjects initially recruited, 395 attended at least one follow-up visit and had interpretable skin tests results. The study protocol was approved by the Ethical Committee of Sacré-Coeur Hospital, Montreal, Canada. The subjects gave written consent to their participation when recruited in this cohort study.

\section{Study design}

The subjects in animal-health technology were reassessed at 8, 20, 32 and 44 months after starting the programme. The majority of students attended the 20 - $(n=345)$ and $32-$ month $(n=355)$ visits. There were 136 students at the 8-month assessment because the others had not been exposed to laboratory animals since starting in the programme; these students were seen at the 20- and 32-month assessments. Finally, 98 subjects attended the longest programme and were seen up to the 44-month assessment.

\section{Study methods}

At the time of entry into the apprenticeship programme and at each follow-up visit, each student answered a respiratory questionnaire derived from the standardized questionnaire of the International Union Against Tuberculosis and Lung Diseases (IUATLD) [8]. Information was obtained on physician-diagnosed asthma, personal allergic conditions and familial asthma. Symptoms suggestive of asthma included wheezing, chest tightness, shortness of breath, or cough under usual conditions or under such conditions as exercise or exposure to cold air, strong odours, smoke, or dusts. Respiratory symptoms and $\mathrm{RC}$ on contact with pets and pollens were also documented.

Skin tests were done with the prick method [9] using
11 common inhalants: mixed trees, mixed grass, and ragweed pollens; Alternaria, Aspergillus, and Hormodendrum; feathers; Dermatophagoides farinae and D. pteronyssinus; and cat and dog dander (Omega, Montreal, Canada). For mite-derived allergens and cat dander, standardized extracts were used. Histamine phosphate $\left(1 / 200 \mathrm{~g} \cdot \mathrm{mL}^{-1}\right)$ was used as a positive control, and diluent (glycerine, $50 \%$ ), as a negative control. The largest weal diameter was assessed 10$15 \mathrm{~min}$ after introduction of the antigen. A positive reaction was defined as a weal $\geqslant 3 \mathrm{~mm}$ in the absence of reaction to the diluent and in the presence of a positive reaction to histamine phosphate. Contrary to a previous publication by the present authors in which atopy was defined as at least two positive reactions to the common inhalants [3], in the present study atopy was defined as one positive reaction in order to have no occurrence in nonatopic subjects at baseline in the case of skin reactions to mites.

In addition, skin-prick tests were performed with extracts of aeroallergens potentially present in the students' working areas, specifically urinary proteins from rat, mouse, and rabbit (Pharmacia Allergon $\mathrm{AB}$, Angelholm, Sweden), as well as rabbit dander (Omega). All extracts were obtained before the beginning of the study in sufficient amounts to perform the total estimated number of skin tests to the end of the project. The skin-prick tests were performed by the same nurse throughout the study.

Skin sensitization to a specific agent was considered positive if sensitization developed at one or the other of the follow-up visits and remained positive at a later visit when three assessments were performed. The same criteria were applied for incident symptoms.

Spirometry with the assessment of forced expiratory volume in one second (FEV1) and forced vital capacity (FVC) was carried out using a Collins apparatus (Survey/1 Plus Collins, Braintree, MA, USA) according to published standards [10]. Methacholine inhalation tests were performed using a Wright's nebulizer (Roxon Meditech Ltd, Montreal, Quebec, Canada) (output $=0.14 \mathrm{~mL} \cdot \mathrm{min}^{-1}$ ) at tidal volume breathing for $2 \mathrm{~min}$ according to guidelines slightly modified from those of the

European Respiratory Society [11]. The procedure for performing the methacholine test was modified as described elsewhere to take into account the absence of an on-site physician [12]. The provocative concentration causing a $20 \%$ fall in FEV1 (PC20) was interpolated from individual dose-response curves drawn on a semi-logarithmic scale using non-cumulative doses. Reference values for FEV1 and FEV1/FVC were taken from KNUDSON et al. [13]. Bronchial hyperresponsiveness was set at $\leqslant 16 \mathrm{mg} \cdot \mathrm{mL}^{-1}[14]$.

\section{Exposure assessment}

The number of hours spent in contact with rodents was considered as a potential determinant for the development of the outcomes. Three categories $(\leqslant 16$, $17-\leqslant 52,>52 \mathrm{~h})$ that best delineated the frequency distribution were set previously [3]. 


\section{Statistical analysis}

The cohort of students was divided into two groups according to atopic status at baseline. The outcomes studied were: 1) skin sensitization to mites; 2) skin sensitization to specific laboratory animal-derived allergens; 3) nasoocular symptoms; 4) work-related respiratory symptoms; 5) occupational RC defined as the association of the development of skin sensitization to at least one specific programme-derived allergen and at least one nasoocular symptom; and 6) probable OA defined as the association of the development of skin sensitization to at least one specific programme-derived allergen and significant changes (3.2-fold difference or more) in PC20. The independent variables in the analyses assessed at baseline included: atopy and immediate skin reaction to pets, history of hay fever, asthma, exercise-induced respiratory symptoms, cold air-induced respiratory symptoms, perannual rhinitis, rhinitis on contact with pets, respiratory symptoms in the pollen season, and familial history of asthma as well as PC20 (dichotomized into $\leqslant 32$ versus $>32 \mathrm{mg} \cdot \mathrm{mL}^{-1}$ and $\leqslant 16$ versus $\left.>16 \mathrm{mg} \cdot \mathrm{mL}^{-1}\right)$. Univariate analyses were used separately for each group to evaluate odds ratios (OR) and $95 \%$ CI for the effect of several host factors on each outcome. Multivariate logistic regression analyses were performed for each group and each outcome with the independent variables meeting the 0.10 level of significance in the univariate analyses. In the individual logistic regression analyses to estimate the OR for the incidence of a given outcome, only the subjects free of this condition at baseline were included. Statistical analyses were performed using the SPSS software package. The level of statistical significance was set at $\mathrm{p}<0.05$ (two-sided).

\section{Results}

Of the 395 eligible subjects, $212(54 \%)$ were atopic and 183 , nonatopic. Table 1 shows the prevalence of the study outcomes at baseline as well as the number of incident cases during follow-up. The incidence of skin positivity to mites, work-related $\mathrm{RC}$, respiratory symptoms, specific immunological sensitization and occupational RC was higher in atopic subjects than in nonatopic apprentices. The incidence of probable OA was also greater in atopic than in nonatopic subjects.
Table 2. - Respiratory symptoms suggestive of asthma at baseline (prevalent) and during follow-up (incidence) according to incidence of probable occupational asthma and atopic status

\begin{tabular}{|c|c|c|c|}
\hline & \multicolumn{3}{|c|}{ Probable occupational asthma } \\
\hline & \multicolumn{2}{|c|}{ Present } & \multirow[t]{2}{*}{ Absent } \\
\hline & Atopic & Nonatopic & \\
\hline Subjects (n) & 24 & 6 & 367 \\
\hline \multicolumn{4}{|l|}{$\begin{array}{l}\text { Symptoms } \\
\text { suggestive } \\
\text { of asthma }\end{array}$} \\
\hline At baseline & $9(37.5)$ & 0 & $59(16.1)$ \\
\hline Incident & $8 / 15(53.3)$ & $1 / 6(16.7)$ & $51 / 308(16.6)$ \\
\hline \multicolumn{4}{|l|}{$\begin{array}{l}\text { Exercise-induced } \\
\text { symptoms }\end{array}$} \\
\hline At baseline & $11(45.8)$ & 0 & $70(19.1)$ \\
\hline Incident & $6 / 13(46.2)$ & 1/6 (16.7) & $50 / 297(16.8)$ \\
\hline \multicolumn{4}{|l|}{$\begin{array}{l}\text { Symptoms on } \\
\text { exposure to } \\
\text { cold air }\end{array}$} \\
\hline At baseline & $5(20.8)$ & 0 & $53(14.4)$ \\
\hline Incident & $9 / 19(47.4)$ & $1 / 6(16.7)$ & 28/314 (8.9) \\
\hline
\end{tabular}

Data are presented as $\mathrm{n}(\%) ;{ }^{*}$ : at least two of the following symptoms: wheezing, chest tightness, dyspnoea, awakening at night with cough; ${ }^{\circ}$ : the denominator is the number of subjects without symptoms at baseline.

Among the 131 subjects with skin reactivity to mites at baseline, 14\% had reported a physician-diagnosed asthma and 64.8\% nonseasonal rhinitis; in contrast, among subjects without skin reactivity to mites at baseline, the proportions were respectively $6.3 \%$ and $30.4 \%$. Table 2 illustrates that only one nonatopic subject with probable OA also developed respiratory symptoms suggestive of asthma and symptoms induced by exercise and cold air, while $>50 \%$ atopic subjects with OA also developed symptoms suggestive of asthma. The incidence of symptoms suggestive of asthma, as well as of symptoms induced by exercise and cold air was more than two-fold in apprentices who developed probable OA than in the other members of the cohort.

Table 3 shows the proportions of atopic and nonatopic subjects developing specific sensitization to rodents, occupational rhinoconjunctivitis and probable OA according to number of hours of exposure to rodents. Among atopic subjects, a high proportion

Table 1.-Skin reactivity to common and specific allergens, work-related symptoms, and occupational diseases at baseline (prevalent) and during follow-up (incidence) according to atopic status

\begin{tabular}{|c|c|c|c|c|c|c|}
\hline & \multicolumn{3}{|c|}{ Atopic $n=212$} & \multicolumn{3}{|c|}{ Nonatopic $n=183$} \\
\hline & At baseline & Incident $^{\#}$ & Absent $\#$ & At baseline & Incident $^{\#}$ & Absent $\#$ \\
\hline Skin reactivity to mites & $131(61.8)$ & 15/81 (18.5) & 66/81 (81.5) & $0(0)$ & $17 / 183(9.3)$ & $166 / 183(90.7)$ \\
\hline Work-related rhinoconjunctivitis & $30(14.2)$ & $82 / 182(45.1)$ & 100/182 (54.9) & $1(0.6)$ & 33/182 (18.0) & $149 / 182(81.4)$ \\
\hline Work-related respiratory symptoms & $0(0)$ & 24/212 (11.3) & $188 / 212(88.7)$ & $0(0)$ & $3 / 183(1.6)$ & $180 / 183(98.4)$ \\
\hline Specific sensitization & $14(6.6)$ & 67/198 (33.8) & 131/198 (66.2) & $1(0.6)$ & 18/182 (9.8) & $164 / 182(89.6)$ \\
\hline Occupational rhinoconjunctivitis & $9(4.2)$ & $51 / 203(25.1)$ & $152 / 203(74.9)$ & $0(0)$ & $11 / 183(6.0)$ & $172 / 183(94.0)$ \\
\hline Probable occupational asthma & - & $24 / 67^{\oplus}(35.8)$ & & - & $6 / 18^{\oplus}(33.3)$ & \\
\hline
\end{tabular}

Data are presented as occurrence of outcome n (\%); ${ }^{\#}$ : the denominator is the number of subjects at risk (i.e., without the outcome at baseline); ${ }^{\top}$ : the denominator is the number of cases of specific immunological sensitization. 
Table 3. - Skin reactivity to specific allergens, work-related rhinoconjunctivitis, and occupational diseases according to atopic status and hours of exposure to rodents

\begin{tabular}{|c|c|c|}
\hline Outcome (hrs of exposure) & Atopic & Nonatopic \\
\hline \multicolumn{3}{|c|}{ Specific immunological sensitization } \\
\hline$\leqslant 16$ & $35 / 78(44.9)$ & $3 / 52(5.8)$ \\
\hline 17 to $\leqslant 52$ & $20 / 86(23.3)$ & $4 / 78(5.1)$ \\
\hline$>52$ & $12 / 34(35.3)$ & $11 / 52(21.2)$ \\
\hline \multicolumn{3}{|l|}{ Work-related rhinoconjunctivitis } \\
\hline$\leqslant 16$ & $26 / 61(42.6)$ & $4 / 52(7.7)$ \\
\hline 17 to $\leqslant 52$ & $30 / 77(39.0)$ & $11 / 77(14.3)$ \\
\hline$>52$ & $20 / 34(58.8)$ & $17 / 52(32.7)$ \\
\hline \multicolumn{3}{|l|}{ Occupational rhinoconjunctivitis } \\
\hline$\leqslant 16$ & $21 / 73(28.8)$ & $1 / 52(2.0)$ \\
\hline 17 to $\leqslant 52$ & $16 / 86(18.6)$ & $2 / 78(2.6)$ \\
\hline$>52$ & $8 / 34(23.5)$ & $7 / 52(13.5)$ \\
\hline \multicolumn{3}{|l|}{ Probable occupational asthma } \\
\hline$\leqslant 16$ & $12 / 78(15.4)$ & $2 / 52(3.8)$ \\
\hline 17 to $\leqslant 52$ & $9 / 86(10.5)$ & $1 / 78(1.3)$ \\
\hline$>52$ & $3 / 34(8.8)$ & $3 / 52(5.8)$ \\
\hline
\end{tabular}

Data are presented as susjects with outcome (n (\%)).

developed specific sensitization and occupational rhinitis at the lowest duration of exposure and no increase was seen with higher duration; on the other hand, among nonatopics, the incidence of the same outcomes clearly augmented with the number of hours of exposure. Although the number of new case of probable OA was small, it was noted that atopic subjects appeared more likely to develop probable OA than nonatopics at the two lowest categories of exposure, but that the proportions were similar in atopic $(8.8 \%)$ and nonatopic $(5.8 \%)$ individuals at the highest exposure category.

Table 4 gives the results of the nonadjusted logistic regression analyses. Having a mother with asthma was a significant factor associated with the development of skin reactivity to mites in atopic subjects whereas smoking was the only significantly associated factor in nonatopic subjects. For the development of specific sensitization to a work-related antigen, several factors were found to be contributive but in atopic subjects only. Perannual rhinitis, respiratory symptoms on contact with pets, and a $\mathrm{PC}_{20}$ value $\leqslant 8$ and $\leqslant 32 \mathrm{mg} \cdot \mathrm{mL}^{-1}$ were associated with work-related $\mathrm{RC}$ for both atopic and nonatopic subjects. Whereas several factors were significant predictors of workrelated respiratory symptoms, occupational rhinoconjunctivits and probable $\mathrm{OA}$ in atopic subjects, having a $\mathrm{PC}_{20} \leqslant 32 \mathrm{mg} \cdot \mathrm{mL}^{-1}$ was the only significant predictor of occupational $\mathrm{RC}$ in both atopic and nonatopic individuals.

Tables 5 and 6 show the results of the multivariate analysis. It can be seen that having a mother with asthma in atopic subjects and smoking in nonatopic subjects were significantly associated with the incidence of skin reactivity to mites, a nonwork-related environmental allergen. As regards work-related RC symptoms, the predictive factors in atopic subjects (rhinitis on contact with pets, immediate skin reactivity to pets) and in nonatopic subjects (perannual rhinitis, respiratory symptoms on contact with pets, and a $\mathrm{PC} 20 \leqslant 32 \mathrm{mg} \cdot \mathrm{mL}^{-1}$ ) were different. In the case of work-related respiratory symptoms, significant determinants (rhinitis on contact with pets, immediate skin reactivity to pets, a $\mathrm{PC}_{20} \leqslant 32 \mathrm{mg} \cdot \mathrm{mL}^{-1}$ ) were found only in atopic subjects. Table 6 shows that rhinitis on contact with pets, and having a PC20 $\leqslant 32 \mathrm{mg} \cdot \mathrm{mL}^{-1}$ were associated with specific immunological sensitization in atopic subjects. No factor was a significant determinant in nonatopic subjects. Perannual rhinitis and immediate skin reactivity to pets were significantly associated with occupational $\mathrm{RC}$ in atopic subjects, whereas a $\mathrm{PC} 20 \leqslant 32 \mathrm{mg} \cdot \mathrm{mL}^{-1}$ was significantly associated with occupational RC for both atopic and nonatopic subjects. Finally, skin reactivity to pets was significantly associated with probable $\mathrm{OA}$ in atopic subjects.

\section{Discussion}

In a prospective cohort of apprentices starting exposure to laboratory animals, the present authors previously identified several factors associated with the development of IgE-mediated sensitization to laboratory-animal allergens. These were atopy and respiratory symptoms in the pollen season [3]. The determinants for probable OA were baseline skin reactivity to pets, bronchial responsiveness $\left(\mathrm{PC}_{20} \leqslant\right.$ $32 \mathrm{mg} \cdot \mathrm{mL}^{-1}$ ) and FEV1 [4]. In this cohort of laboratory workers, 18 of the 85 incident cases of sensitization and six of the 30 incident cases of probable OA were nonatopic. Although atopy is clearly a major risk factor, work-related specific sensitization and probable OA do occur in nonatopic subjects as well. It is therefore of interest to know whether the secondary risk factors differ in atopic and nonatopic subjects. In a previous paper [3], by the present authors, the interaction between atopy and the other factors was not studied in the analysis because of the small number of cases. Therefore, in the study presented here parallel analyses were performed in atopic and nonatopic subjects. Such separate analyses have rarely been carried out. HEEDERIK et al. [7] examined the effect of ranked levels of exposure in 650 atopic and nonatopic subjects exposed to laboratory animals. These authors found that atopic workers in three levels of antigen exposure had a constant threefold increased sensitization risk compared with nonexposed workers, while nonatopic workers showed an increased sensitization risk with higher exposure category. These findings were confirmed in the present authors study for the development of specific sensitization and occupational rhinoconjunctivitis

In the present study, for most analyses, except for work-related respiratory symptoms in nonatopic subjects $(n=3)$, the number of incident outcomes was sufficient to allow firm conclusions. Indeed, when the incidence is $<10$, the results from a logistic regression analysis may be spurious or imprecise as discussed elsewhere [15].

In atopic subjects, certain factors such as rhinitis on contact with pets and immediate skin reactivity to pets as well as having a $\mathrm{PC} 20 \leqslant 32 \mathrm{mg} \cdot \mathrm{mL}^{-1}$ were associated with more than one outcome. The ORs for work-related 
Table 4. - Odds ratios (OR) and 95\% confidence intervals $(\mathrm{Cl})$ for skin reactivity to common and specific allergens, workrelated symptoms, and occupational diseases in relation to host factors

\begin{tabular}{|c|c|c|}
\hline Outcome and factor & Atopic & Nonatopic \\
\hline \multicolumn{3}{|l|}{ Skin reactivity to mites } \\
\hline Mother with asthma & $3.9(0.9-16.0)$ & \\
\hline Smoking & & $4.8(1.7-13.8)$ \\
\hline \multicolumn{3}{|l|}{ Work-related rhinoconjunctivitis } \\
\hline Rhinitis on contact with pets & $4.2(2.3-7.7)$ & \\
\hline Perannual rhinitis & $4.0(2.1-7.4)$ & $2.4(1.0-5.4)$ \\
\hline Respiratory symptoms on contact with pets & $2.6(0.8-8.1)$ & $7.6(1.2-47.5)$ \\
\hline Immediate skin reaction to pets & $4.6(2.3-9.1)$ & \\
\hline $\mathrm{PC} 20<32 \mathrm{mg} \cdot \mathrm{mL}^{-1}$ & $1.8(1.0-3.3)$ & $2.9(1.3-6.3)$ \\
\hline $\mathrm{PC} 20<8 \mathrm{mg} \cdot \mathrm{mL}^{-1}$ & $1.9(0.9-4.0)$ & $3.8(1.3-10.8)$ \\
\hline \multicolumn{3}{|l|}{ Work-related respiratory symptoms } \\
\hline Hay fever & $6.1(2.3-15.9)$ & \\
\hline Rhinitis on contact with pets & $33.4(4.4-252.1)$ & \\
\hline Perannual rhinitis & $16.9(2.2-127.3)$ & \\
\hline Respiratory symptoms on contact with pets & $8.7(3.2-23.6)$ & \\
\hline Immediate skin reaction to pets & $13.5(4.4-41.4)$ & \\
\hline $\mathrm{PC}_{20}<32 \mathrm{mg} \cdot \mathrm{mL}^{-1}$ & $8.0(2.6-24.4)$ & \\
\hline $\mathrm{PC} 20<8 \mathrm{mg} \cdot \mathrm{mL}^{-1}$ & $4.3(1.8-10.3)$ & \\
\hline \multicolumn{3}{|l|}{ Specific immunological sensitization } \\
\hline Hay fever & $4.0(1.5-10.7)$ & \\
\hline Rhinitis on contact with pets & $4.0(2.1-7.7)$ & \\
\hline Perannual rhinitis & $4.6(2.2-9.5)$ & \\
\hline Respiratory symptoms on contact with pets & $5.1(1.7-15.5)$ & \\
\hline Immediate skin reaction to pets & $3.4(1.7-6.6)$ & \\
\hline $\mathrm{PC}_{20}<32 \mathrm{mg} \cdot \mathrm{mL}^{-1}$ & $4.0(2.0-7.7)$ & \\
\hline $\mathrm{PC} 20<8 \mathrm{mg} \cdot \mathrm{mL}^{-1}$ & $2.9(1.4-6.2)$ & \\
\hline \multicolumn{3}{|l|}{ Occupational rhinoconjunctivitis } \\
\hline Rhinitis on contact with pets & $3.9(2.0-7.6)$ & \\
\hline Perannual rhinitis & $4.9(2.2-11.1)$ & \\
\hline Respiratory symptoms on contact with pets & $2.4(0.9-6.8)$ & \\
\hline Immediate skin reaction to pets & $5.6(2.9-11.1)$ & \\
\hline $\mathrm{PC} 20<32 \mathrm{mg} \cdot \mathrm{mL}^{-1}$ & $3.6(1.8-7.1)$ & $4.1(1.1-15.2)$ \\
\hline $\mathrm{PC} 20<8 \mathrm{mg} \cdot \mathrm{mL}^{-1}$ & $2.6(1.2-5.4)$ & \\
\hline \multicolumn{3}{|l|}{ Probable occupational asthma } \\
\hline Respiratory symptoms on contact with pets & $3.2(1.1-9.7)$ & \\
\hline Immediate skin reaction to pets & $4.1(1.6-10.2)$ & \\
\hline
\end{tabular}

Data are presented as OR $(95 \%$ CI). Nonadjusted analyses. PC20: provocative concentration causing a $20 \%$ fall in forced expiratory volume in one second.

respiratory symptoms and their CIs, are larger for most risk factors in comparison with the ORs for the other outcomes (i.e., work-related rhinoconjunctivitis, occupational rhinitis or probable OA) (table 4). This may be a spurious effect, indeed most subjects with work-related respiratory symptoms also have positive skin reaction to pets (20/24) and all, except one, have symptoms of rhinitis in contact with pets (table 5). However, when rhinitis in contact with pets is taken into account in the multiple logisitic regression analysis, the OR for work-related respiratory symptoms due to skin reaction to pets $(\mathrm{OR}=6.1)$ is comparable to the other ORs shown in table 4.

Rhinitis symptoms on contact with pets and immediate skin reactivity to pets might have been suspected to be reasonable predictors of the likelihood of developing one or the other of the selected outcomes in atopic subjects. In particular, the relationship between the latter risk factor and the development of specific immunological sensitization to laboratory animals could be attributable to crossimmunological reactivity between these mammalian species, as discussed previously $[5,16]$, major allergens belonging to the "same super-family of proteins" [17]. However, increased bronchial responsiveness could not have been so readily suspected. As previously discussed, it would therefore seem interesting to consider following-up subjects exposed to laboratory animals by using both skin-prick testing and bronchial responsiveness assessment [3] although positive predictive values are low, at least for a follow-up of $3-4 \mathrm{yrs}$ as in the current study (in the order of $30-50 \%$ ).

The most interesting finding of the present study is the fact that not only do a substantial number of nonatopic subjects develop specific sensitization $(18 / 85,21.2 \%)$ and probable OA $(6 / 30,20 \%)$, but the associated factors differ in atopic and in nonatopic subjects. For instance, perannual rhinitis and having a $\mathrm{PC} 20 \leqslant 32 \mathrm{mg} \cdot \mathrm{mL}^{-1}$ were significantly associated with the development of work-related RC symptoms in nonatopic subjects, but not in atopic individuals. It is reasonable to assume that having perannual rhinitis symptoms may place someone more at risk to develop

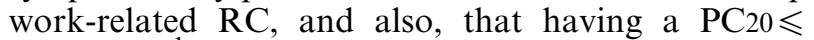
$32 \mathrm{mg} \cdot \mathrm{mL}^{-1}$ is a reflection of upper and/or lower 
Table 5. - Odds ratios (OR) and 95\% confidence intervals $(\mathrm{Cl})$ for skin reactivity to common allergens, and work-related symptoms in relation to host factors. In multivariate logistic regression analyses adjusting each factor to the others

\begin{tabular}{|c|c|c|c|c|c|c|c|}
\hline \multirow[t]{3}{*}{ Outcome Factor } & & \multicolumn{3}{|c|}{ Atopic } & \multicolumn{3}{|c|}{ Nonatopic } \\
\hline & & \multicolumn{2}{|c|}{$\begin{array}{l}\text { Number of subjects } \\
\text { with factor/outcome }\end{array}$} & \multirow[t]{2}{*}{ OR $(95 \% \mathrm{CI})$} & \multicolumn{2}{|c|}{$\begin{array}{l}\text { Number of subjects } \\
\text { with factor/outcome }\end{array}$} & \multirow[t]{2}{*}{ OR $(95 \% \mathrm{CI})$} \\
\hline & & Present & Absent & & Present & Absent & \\
\hline \multicolumn{8}{|l|}{ Skin reactivity to mites } \\
\hline Mother with asthma & $\begin{array}{l}\text { Present } \\
\text { Absent }\end{array}$ & $\begin{array}{r}4 \\
10\end{array}$ & $\begin{array}{r}5 \\
61\end{array}$ & $4.88(1.11-21.33)$ & & & \\
\hline Smoking & $\begin{array}{l}\text { Present } \\
\text { Absent }\end{array}$ & & & & $\begin{array}{r}6 \\
10\end{array}$ & $\begin{array}{r}19 \\
143\end{array}$ & $4.51(1.47-3.83)$ \\
\hline \multicolumn{8}{|l|}{ Work-related rhinoconjunctivitis } \\
\hline Rhinitis on contact with pets & $\begin{array}{l}\text { Present } \\
\text { Absent }\end{array}$ & $\begin{array}{l}44 \\
34\end{array}$ & $\begin{array}{l}24 \\
81\end{array}$ & $3.44(1.77-6.69)$ & & & \\
\hline Perannual rhinitis & $\begin{array}{l}\text { Present } \\
\text { Absent }\end{array}$ & & & & $\begin{array}{l}11 \\
21\end{array}$ & $\begin{array}{r}23 \\
121\end{array}$ & $2.60(1.04-6.35)$ \\
\hline $\begin{array}{l}\text { Respiratory symptoms on } \\
\text { contact with pets }\end{array}$ & $\begin{array}{l}\text { Present } \\
\text { Absent }\end{array}$ & & & & $\begin{array}{r}3 \\
29\end{array}$ & $\begin{array}{r}2 \\
142\end{array}$ & $6.26(0.93-42.09)$ \\
\hline Immediate skin reaction to pets & $\begin{array}{l}\text { Present } \\
\text { Absent }\end{array}$ & $\begin{array}{l}33 \\
45\end{array}$ & $\begin{array}{l}16 \\
88\end{array}$ & $2.97(1.43-6.21)$ & & & \\
\hline $\mathrm{PC} 20<32 \mathrm{mg} \cdot \mathrm{mL}^{-1}$ & $\begin{array}{l}\text { Present } \\
\text { Absent }\end{array}$ & & & & $\begin{array}{l}15 \\
17\end{array}$ & $\begin{array}{r}34 \\
110\end{array}$ & $3.21(1.40-7.34)$ \\
\hline \multicolumn{8}{|c|}{ Work-related respiratory symptoms } \\
\hline Rhinitis on contact with pets & $\begin{array}{c}\text { Present } \\
\text { Absent }\end{array}$ & $\begin{array}{r}23 \\
1\end{array}$ & $\begin{array}{r}75 \\
115\end{array}$ & $18.18(2.32-142.5)$ & & & \\
\hline Immediate skin reaction to pets & $\begin{array}{l}\text { Present } \\
\text { Absent }\end{array}$ & $\begin{array}{r}20 \\
4\end{array}$ & $\begin{array}{r}50 \\
139\end{array}$ & $6.11(1.86-20.03)$ & & & \\
\hline $\mathrm{PC} 20<32 \mathrm{mg} \cdot \mathrm{mL}^{-1}$ & $\begin{array}{l}\text { Present } \\
\text { Absent }\end{array}$ & $\begin{array}{r}20 \\
4\end{array}$ & $\begin{array}{r}73 \\
117\end{array}$ & $3.94(1.18-13.15)$ & & & \\
\hline
\end{tabular}

\#: The number of cases with the outcome present or absent is given, as is the number of cases with the factor present or absent. PC20: provocative concentration causing a $20 \%$ fall in forced expiratory volume in one second.

airways responsiveness. In atopic subjects, these factors are individually associated with the incidence of work-related RC symptoms, but are overshadowed by the presence of atopy, and symptomatology on contact with pets in a multivariate analysis.

The present authors found that smoking was

Table 6. - Odds ratios (OR) and 95\% confidence intervals $(\mathrm{Cl})$ for skin reactivity to specific allergens, and occupational diseases in relation to host factors. In multivariate logistic regression analyses adjusting each factor to the others

\begin{tabular}{|c|c|c|c|c|c|c|c|}
\hline \multirow[t]{3}{*}{ Outcome Factor } & & \multicolumn{3}{|c|}{ Atopic } & \multicolumn{3}{|c|}{ Nonatopic } \\
\hline & & \multicolumn{2}{|c|}{$\begin{array}{l}\text { Number of subjects } \\
\text { with factor/outcome }\end{array}$} & \multirow[t]{2}{*}{ OR $(95 \% \mathrm{CI})$} & \multicolumn{2}{|c|}{$\begin{array}{l}\text { Number of subjects } \\
\text { with factor/outcome }\end{array}$} & \multirow[t]{2}{*}{ OR $(95 \% \mathrm{CI})$} \\
\hline & & Present & Absent & & Present & Absent & \\
\hline \multicolumn{8}{|l|}{ Specific immunological sensitization } \\
\hline Rhinitis on contact with pets & Present & 40 & 37 & $3.71(1.83-7.52)$ & & & \\
\hline $\mathrm{PC} 20<32 \mathrm{mg} \cdot \mathrm{mL}^{-1}$ & Present & $\begin{array}{l}19 \\
37\end{array}$ & 34 & $2.95(1.46-5.95)$ & & & \\
\hline \multicolumn{8}{|l|}{ Occupational rhinoconjunctivitis } \\
\hline Perannual rhinitis & $\begin{array}{l}\text { Present } \\
\text { Absent }\end{array}$ & $\begin{array}{r}39 \\
8\end{array}$ & $\begin{array}{l}81 \\
75\end{array}$ & $2.90(1.21-6.95)$ & & & \\
\hline Immediate skin reaction to pets & $\begin{array}{l}\text { Present } \\
\text { Absent }\end{array}$ & $\begin{array}{l}28 \\
19\end{array}$ & $\begin{array}{r}34 \\
121\end{array}$ & $3.20(1.50-6.85)$ & & & \\
\hline $\mathrm{PC} 20<32 \mathrm{mg} \cdot \mathrm{mL}^{-1}$ & $\begin{array}{c}\text { Present } \\
\text { Absent }\end{array}$ & $\begin{array}{l}31 \\
16\end{array}$ & $\begin{array}{r}55 \\
101\end{array}$ & $2.13(1.00-4.56)$ & $\begin{array}{l}6 \\
4\end{array}$ & $\begin{array}{r}45 \\
123\end{array}$ & $4.10(1.11-15.20)$ \\
\hline \multicolumn{8}{|l|}{ Probable occupational asthma } \\
\hline Immediate skin reaction to pets & $\begin{array}{l}\text { Present } \\
\text { Absent }\end{array}$ & $\begin{array}{r}16 \\
8\end{array}$ & $\begin{array}{l}42 \\
85\end{array}$ & $4.05(1.60-10.21)$ & & & \\
\hline
\end{tabular}

\#: The number of cases with the outcome present or absent is given, as is the number of cases with the factor present or absent. PC20: provocative concentration causing a $20 \%$ fall in forced expiratory volume in one second. 
associated with the development of skin reactivity to mites in nonatopic individuals. Although smoking has been associated in some studies with the development of airway hyperresponsiveness, its association with the development of IgE-mediated sensitization to common allergens has not been documented. Increase in total $\mathrm{IgE}$ levels is associated with both smoking and atopy, but separately [18, 19]. Atopic markers such as increased specific IgE levels and immediate skin reactivity to common inhalants seem to be even less common in smokers [20]. Smoking has however been found to be a determinant of IgE-mediated sensitization to such occupational agents as psyllium [21] and platinum salts [22]. However, smoking was not found to be associated with the development of specific skin reaction to laboratory animals in previously published studies by Cullinan et al. [2] and HeEDERIK et al. [7]. The results of the present study, obtained in nonatopic subjects and with a small number of cases, are in accordance with these findings. However, the results of this study do not provide a clear statement on the role of cigarette smoking in the development of the outcomes studied here. The absence of an association between smoking sensitization and work-related allergens could be due to the young age of the subjects (mean age 19.5 $\pm 2.9 \mathrm{yrs}$ ). Including such subjects allowed the present study, however, to observe the effects of work-related exposure independently of the effects of smoking.

The incidence of skin sensitization to mites was higher in atopic than in nonatopic subjects which was expected. However, the incidence of sensitization to this common allergen was lower than for most workrelated outcomes.

The prospective design of this study performed in a cohort of apprentices, enabled the present authors to assess the subjects' baseline atopic and airway responsiveness status, and medical history before any/or not more than 3-months exposure to the occupational allergens took place. This approach allows reduction in the bias that may otherwise be present when a cohort is assembled after some years of exposure [23]. In addition, it allows the natural history of the development of specific sensitization and OA to be studied, which is difficult in the case of common asthma as discussed elsewhere and as presented when the study was initiated [6].

In conclusion, as determinants of sensitization, symptoms and diseases differ in atopic and nonatopic subjects, it might be suggested to use such discrete analyses in population surveys.

Acknowledgements. The authors express their gratitude to the technicians, principally $\mathrm{J}$. L'Archevêque, and to nurse M. Magnan, who played a key role in the recruitment of subjects and the handling of results. They also thank all those responsible at the participating teaching institutions and all of the students who took part in the study. Finally, they acknowledge the collaboration of L. Schubert for reviewing the manuscript.

\section{References}

1. Gordon S, Newman Taylor AJ. Animal, insect, and shellfish allergy. In: Bernstein IL, Chan-Yeung $\mathrm{M}$, Malo J-L, Bernstein DI, eds. Asthma in the Workplace. 2nd Edn. New York, Marcel Dekker Inc., 1999; pp. 399-424.

2. Cullinan $\mathrm{P}$, Cook A, Gordon S, et al. Allergen exposure, atopy and smoking as determinants of allergy to rats in a cohort of laboratory employees. Eur Respir J 1999; 13: 1139-1143.

3. Gautrin D, Ghezzo H, Infante-Rivard C, Malo J-L. Incidence and determinants of IgE-mediated sensitisation in apprentices: a prospective study. Am J Respir Crit Care Med 2000; 162: 1222-1228.

4. Gautrin D, Infante-Rivard C, Ghezzo H, Malo JL. Incidence and determinants of probable occupational asthma in apprentices exposed to laboratory animals. Am J Respir Crit Care Med 2001; 163: 899-904.

5. Slovak AJM, Hill RN. Does atopy have any predictive value for laboratory animal allergy? A comparison of different concepts of atopy. Br J Ind Med 1987; 44: 129-132.

6. Gautrin D, Infante-Rivard C, Dao TV, MagnanLarose M, Desjardins D, Malo J-L. Specific IgE-dependent sensitization, atopy and bronchial hyperresponsiveness in apprentices starting exposure to protein-derived agents. Am J Respir Crit Care Med 1997; 155: 1841-1847.

7. Heederik D, Venables KM, Malmberg P, et al. Exposure-response relationships for work-related sensitization in workers exposed to rat urinary allergens: results from a pooled study. J Allergy Clin Immunol 1999; 103: 678-684.

8. Burney PGJ, Laitinen LA, Perdrizet S, et al. an international comparison. Eur Respir J 1989; 2: 940945.

9. Pepys J. Types of allergic reaction. Clin Allergy 1973; 3: 491-509.

10. American Thoracic Society. Standardization of spirometry. Am J Respir Crit Care Med 1995; 152: $1107-$ 1136.

11. Sterk PJ, Fabbri LM, Quanjer PH, et al. Airway responsiveness. Standardized challenge testing with pharmacological, physical and sensitizing stimuli in adults. Report working party standardization of lung function tests European Community for Steel and Coal. Official statement of the European Respiratory Society. Eur Respir J 1993; 6: Suppl. 16, 53-83.

12. Troyanov S, Malo JJ, Cartier A, Gautrin D. Frequency and determinants of exaggerated bronchoconstriction due to methacholine inhalation in epidemiological and clinical setups. Eur Respir J 2000; 16 : 9-14.

13. Knudson RJ, Lebowitz MD, Holberg CJ, Burrows B. Changes in the normal maximal expiratory flowvolume curve with growth and aging. Am Rev Respir Dis 1983; 127: 725-734.

14. Malo JL, Pineau L, Cartier A, Martin RR. Reference values of the provocative concentrations of methacholine that cause $6 \%$ and $20 \%$ changes in forced expiratory volume in one second in a normal population. Am Rev Respir Dis 1983; 128: 8-11.

15. Concato J, Feinstein AR. Monte Carlo methods in clinical research: applications in multivariate analysis. J Invest Med 1997; 45: 394 400.

16. Hollander A, Heederik D, Doekes G. Respiratory 
allergy to rats: exposure-response relationships in laboratory animal workers. Am J Respir Crit Care Med 1997; 155: 562-567.

17. Gordon S. Allergy to furred animals. Clin Exp Allergy 1997; 27: 479-481.

18. Sherrill DL, Halonen M, Burrows B. Relationships between total serum IgE, atopy, and smoking: a twenty-year follow-up analysis. $J$ Allergy Clin Immunol 1994; 94: 954-962.

19. Oryszczyn MP, Annesi-Maesano I, Charpin D, Paty E, Maccario J, Kauffmann F. Relationships of active and passive smoking to total IgE in adults of the epidemiological study of the genetics and environment of asthma, bronchial hyperresponsiveness, and atopy (EGEA). Am J Respir Crit Care Med 2000; 161: 12411246.
20. Wuthrich B, Schindler C, Medici TC, Zellweger JP, Leuenberger P. IgE levels, atopy markers and hay fever in relation to age, sex and smoking status in a normal adult Swiss population. SAPALDIA Team. Int Arch Allergy Immunol 1996; 111: 396-402.

21. Zetterstrom O, Osterman K, Machado L, Johansson SGO. Another smoking hazard: raised serum IgE concentration and increased risk of occupational allergy. BMJ 1981; 283: 1215-1217.

22. Venables KM, Dally MB, Nunn AJ, et al. Smoking and occupational allergy in workers in a platinum refinery. BMJ 1989; 299: 939-942.

23. McDonald C. Study design. In: McDonald JC, ed. Epidemiology of Work Related Diseases. London, the BMJ Publishing Group, 1995; p. 327. 